\begin{tabular}{l|l} 
& $\begin{array}{l}\text { Eastern } \\
\text { European } \\
\text { Countryside }\end{array}$ \\
\hline DOI:1515/eec-2015-0002 & $21^{\prime} 2015$
\end{tabular}

Kristina Knific, Štefan Bojnec

\title{
Agricultural Holdings in Hilly-Mountain Areas in Slovenia before and after the Accession to the European Union
}

\begin{abstract}
This paper presents the questionnaire results of the research on implications of the effects of Slovenia's accession to the European Union (EU) on structural changes in agricultural holdings (AHs) in the case of Škofjeloška hilly-mountain rural areas. The effects are studied based on the analysis of income diversification of AHs three years before the Slovenian accession to the EU in 2000 and six years after the Slovenian accession to the EU in 2010. Strategies of AHs on the basis of the questionnaire were analysed in early 2011. Income diversification of AHs with non-agricultural employment and off-farm incomes is necessary for survival for the majority of AHs. There are observed differences in structural changes in the AHs between areas with different natural conditions for agricultural production, and particularly in the extent and in the direction of structural changes by socioeconomic types of AHs. Structural changes inhibit non-economic objectives of AHs, while non-agricultural employment has a two-way influence.
\end{abstract}

Keywords: agricultural holdings, structural changes, hilly-mountain areas, Slovenia, European Union

\section{Introduction}

With Slovenia's accession to the European Union (EU) in 2004, relatively intensive changes in both the internal and external environment have 
emerged for agricultural holdings (AHs). AHs are the most important operators of rural landscapes as they manage most of the land. Areas with limited opportunities for agricultural production comprise $85 \%$ of Slovenian territory, of which slightly less than $72 \%$ of less favoured areas are situated in hilly-mountain areas (MAFF 2007). These less favoured areas are characterised by lower production potential in agricultural production. Competitiveness of Slovenian agriculture is constrained by the unfavourable size structure and the socio-economic and productive structures of farms. The relative importance of the agricultural sector in the Slovenian economy at the time of accession to the EU was higher than the EU-25 average (MAFF 2007). The gap between the higher shares of gross domestic product (GDP) than employment in agriculture, hunting and forestry in Slovenia between the years 2000 and 2010 decreased as the share of GDP decreased from $3.2 \%$ to $2.1 \%$ and the employment share decreased from $11.9 \%$ to $8.4 \%$ (SORS 2005, 2012b). This suggests that labour productivity of the agricultural, hunting and forestry sector remains relatively lower than in the rest of the Slovenian economy.

The survey of AHs with the written questionnaire is limited to the Škofjeloška area in Slovenia, more specifically the two municipalities: firstly, Škofja Loka, which is economically more developed with relatively favourable conditions for agricultural production, particularly in the flat areas, which comprise Soriško polje; secondly, Gorenje vas-Poljane, which is economically less developed and with a greater distance to urban centres or local markets. In addition, the conditions for agricultural production are relatively poor. The total area of the municipality is located in an area with limited conditions for agricultural production. In addition to the analysis between the two municipalities, the analysis compares the questionnaire survey results among socio-economic types of farms.

\section{Methodology}

\section{Sample}

Data on incomes and strategies of AHs were obtained through personal interviews using the written questionnaire in the sample of $60 \mathrm{AHs}^{1}$. This

\footnotetext{
${ }^{1}$ Data for 2000 are based on EC (2002), Möllers (2006), and Oblak (2002). Data for 2010 are obtained by Knific (2013) using an adjusted written questionnaire by Möllers (2007).
} 
sample represented approximately $5 \%$ of the population of AHs, which were active in agricultural production in 2000. The sample of AHs was within the municipalities selected as a proportional stratified random sample of AHs. The stratums were socio-economic types of AHs (Kovačič 1996, 19-22), with the difference being that the elderly members of AHs older than 64 years were not included in the sampling. For the purpose of research on incomes of AHs by socio-economic types of AHs, the sample included: pure farms, mixed farms, supplementary farms, and farms in abandonment. Following Kovačič (1996) and Udovič, Kovačič and Kramarič (2006), among the pure farms are included AHs without the elderly members of AHs older than 64 years, which complies with the criteria that no one of the core $\mathrm{AH}$ members is employed outside the farm and the annual work unit (AWU), $1 \mathrm{AWU}=1,800$ hours of labour per year, is at least 1.2. Among the mixed farms are included: firstly, AHs in which at least one of the core $\mathrm{AH}$ members is employed on the farm, at least one of the core members is employed outside the farm, and the amount of work in AHs is at least 1.2 AWUs, and secondly, AHs in which all members of AHs are either employed outside the farm or retired or dependent persons and the total AWU is greater than 1.0 if they meet the following conditions: (i) nonelderly farm or pure farm, and (ii) without supplementary activities on the farm. Among supplementary farms are included AHs with supplementary activities on the farm with at least 0.7 AWUs in agricultural activity. Among the farms in the abandonment are included AHs that are not elderly farms with members of AHs older than 64 years, not supplementary farms, and in which their AWU in agricultural activity is smaller than 1.0 AWU.

In the written questionnaire, all views and opinions of AHs on strategies of AHs were measured indirectly by a five-step Likert scale.

\section{Income of AHs}

Incomes of AHs are calculated as the sum of incomes by income sources (Eurostat 2012). Income from agriculture is calculated as the difference between revenues from agricultural activities (revenues from livestock production, revenues from crop production, revenues from other agricultural sources such as services, and rental of machinery) and costs. It also includes net revenues from forestry activity and state support or subsidies to agriculture. In the revenues of livestock and crop production, all revenues from sales and value of domestic consumption are taken into 
account. Among incomes of the supplementary farms from supplementary activities on farms (self-employment), net income is considered. Among incomes of AHs from off-farm employment, net wages of members of AHs are included. Among revenues of AHs, we have also taken into account other allowances of members of AHs, e.g. social assistance and cash contributions from relatives and pensions, and other revenues of AHs such as incomes from securities, partnerships, gambling, leases, and other such benefits.

Real incomes of AHs in 2000 are calculated using the harmonised index of consumer prices between the years 2000 and 2010 (SORS 2012a). The year 2010 is used as the base year of the calculation.

\section{Statistical tests}

The analyses of the differences in arithmetic means of incomes of AHs between the years 2000 and 2010, and between the municipalities of Škofja Loka and Gorenje vas-Poljane, are performed by a t-test and the application of the Statistical Package for the Social Sciences (SPSS). The analyses of the differences in arithmetic means between socio-economic types of AHs (pure farms, mixed farms, supplementary farms, and farms in abandonment) are performed by analysis of variance (One-Way ANOVA) using the SPSS. The acceptable level of risk is at a 5\% significance level.

\section{Empirical Results}

Sample of AHs

The number of AHs where at least one member of the AHs is professionally engaged in agriculture has decreased. The number of AHs in which farms are in abandonment and, thus, are exiting farming has increased. AHs have abandoned farming mainly due to relatively low incomes from agricultural activities (Table 1).

Among the socio-economic types of farms, only the number of supplementary farms has increased, while the number of pure and mixed farms has decreased. The number of mixed farms has been rapidly decreasing. The number of supplementary farms has grown in an area with better natural conditions for agricultural activity and in the close proximity of urban centres. 


\begin{tabular}{|c|c|c|c|c|c|c|c|c|c|c|c|c|c|c|c|c|}
\hline \multirow{4}{*}{ 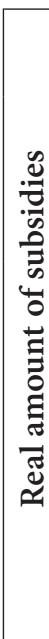 } & \multirow{4}{*}{ 芯 } & 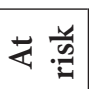 & $\begin{array}{l} \\
8 \\
0\end{array}$ & & & 8 & & & \begin{tabular}{|l|} 
\\
\\
0
\end{tabular} & & & $\begin{array}{l}8 \\
0 \\
0\end{array}$ & & 8 & & \\
\hline & & 营 & 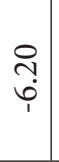 & & & $\begin{array}{c}\hat{1} \\
\infty \\
i\end{array}$ & & & $\stackrel{\infty}{\rightarrow}$ & & & $\begin{array}{l}\stackrel{8}{0} \\
+\end{array}$ & & $\stackrel{\substack{F \\
i}}{i}$ & & \\
\hline & & 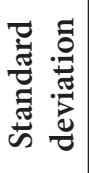 & ڤे & $\overrightarrow{\hat{o}}$ & $\mid \begin{array}{l}\alpha \\
\infty \\
m\end{array}$ & 8ి & $\stackrel{\infty}{\infty}$ & $\frac{m}{m}$ & 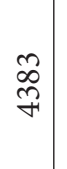 & $\begin{array}{l}\stackrel{2}{0} \\
\stackrel{1}{m}\end{array}$ & 㣽 & 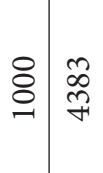 & $\left|\begin{array}{l}\infty \\
\infty \\
m \\
m\end{array}\right|$ & $\mid \begin{array}{l}\infty \\
\infty \\
0\end{array}$ & $\begin{array}{l}0 \\
\stackrel{2}{2} \\
m\end{array}$ & $\vec{\partial}$ \\
\hline & & 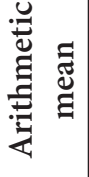 & 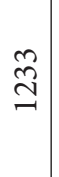 & 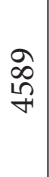 & $\begin{array}{l}0 \\
1 \\
n \\
m \\
m\end{array}$ & $\begin{array}{l}\vec{n} \\
\stackrel{n}{n}\end{array}$ & $\frac{10}{a}$ & 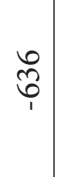 & $\begin{array}{c}n \\
\hat{n} \\
\text { กิ }\end{array}$ & 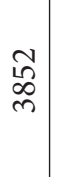 & $\underset{1}{\stackrel{m}{+}}$ & 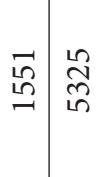 & 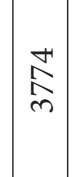 & $\frac{10}{2}$ & $\left|\begin{array}{c}N \\
1 \\
\infty \\
m\end{array}\right|$ & ڤે \\
\hline \multirow{4}{*}{ 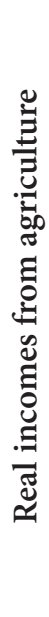 } & \multirow{4}{*}{ 尔 } & 娄蒙 & $\stackrel{\overbrace{}}{0}$ & & & 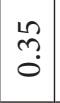 & & & $\begin{array}{l}0 \\
i \\
0 \\
0\end{array}$ & & & $\stackrel{7}{\circ}$ & & $\stackrel{n}{n}$ & & \\
\hline & & 营 & \begin{tabular}{l}
\multirow{H}{*}{} \\
$\stackrel{1}{1}$
\end{tabular} & & & ले & & & $\begin{array}{l}0 \\
\dot{0} \\
1\end{array}$ & & & $\begin{array}{l}\text { तิ } \\
\text { î }\end{array}$ & & 文 & & \\
\hline & & 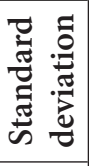 & $\begin{array}{l}\stackrel{\partial}{\Delta} \\
\stackrel{\infty}{ }\end{array}$ & 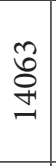 & 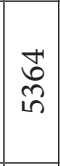 & $\begin{array}{l}\hat{a} \\
\infty \\
\infty\end{array}$ & 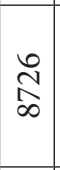 & $\overrightarrow{\hat{T}_{1}}$ & $\underset{\infty}{\vec{N}}$ & $\begin{array}{l}\hat{0} \\
\infty \\
\infty \\
0\end{array}$ & 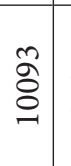 & 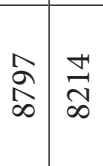 & $\begin{array}{l}0 \\
\infty \\
0 \\
1\end{array}$ & $\mid \begin{array}{c}\mathbb{2} \\
\stackrel{N}{\infty}\end{array}$ & $\begin{array}{c}0 \\
0 \\
\infty \\
\infty \\
-1\end{array}$ & $\begin{array}{l}\bar{\infty} \\
\alpha \\
\alpha\end{array}$ \\
\hline & & 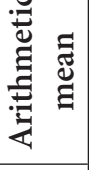 & $\begin{array}{l}\text { 它 } \\
\text { مे }\end{array}$ & $\begin{array}{l}\text { शे } \\
\text { वे }\end{array}$ & 多 & స్ & $\begin{array}{l}0 \\
19 \\
17 \\
15\end{array}$ & $\begin{array}{c}2 \\
\hat{\alpha} \\
1\end{array}$ & $\begin{array}{l}2 \\
0 \\
\infty \\
0 \\
0\end{array}$ & $\begin{array}{l}\text { ర్ } \\
\& \\
0\end{array}$ & $\hat{\sim}$ & 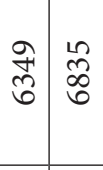 & $\mid \begin{array}{l}\infty \\
\infty \\
+ \\
+\end{array}$ & 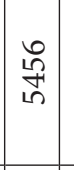 & $\mid \begin{array}{l}\hat{b} \\
0 \\
0\end{array}$ & 总 \\
\hline \multicolumn{3}{|c|}{ z } & 8 & $\stackrel{\infty}{i n}$ & $\uparrow$ & ஓे & 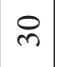 & 0 & ते & নे & 0 & ஓ & 7 & i & $\grave{\lambda}$ & 7 \\
\hline & & & 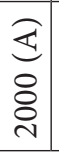 & 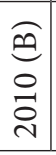 & $\begin{array}{l}\varangle \\
\infty \\
\infty\end{array}$ & $\begin{array}{l}3 \\
3 \\
2 \\
2 \\
0\end{array}$ & $\begin{array}{c}\widehat{\oplus} \\
\vec{\omega}\end{array}$ & $\begin{array}{l}\varangle \\
\infty \\
\infty\end{array}$ & 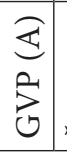 & 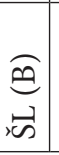 & $\begin{array}{l}\varangle \\
\infty\end{array}$ & 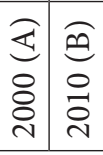 & $\begin{array}{l}4 \\
\infty\end{array}$ & 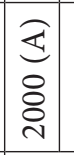 & 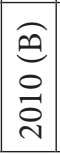 & 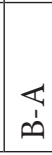 \\
\hline & & & \multicolumn{3}{|c|}{ 量 } & \multicolumn{3}{|c|}{ 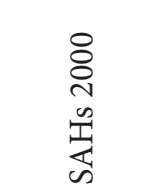 } & \multicolumn{3}{|c|}{ 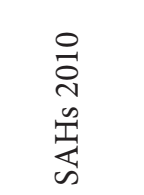 } & \multicolumn{2}{|c|}{ 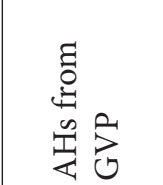 } & \multicolumn{3}{|c|}{ 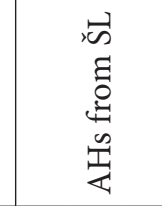 } \\
\hline
\end{tabular}




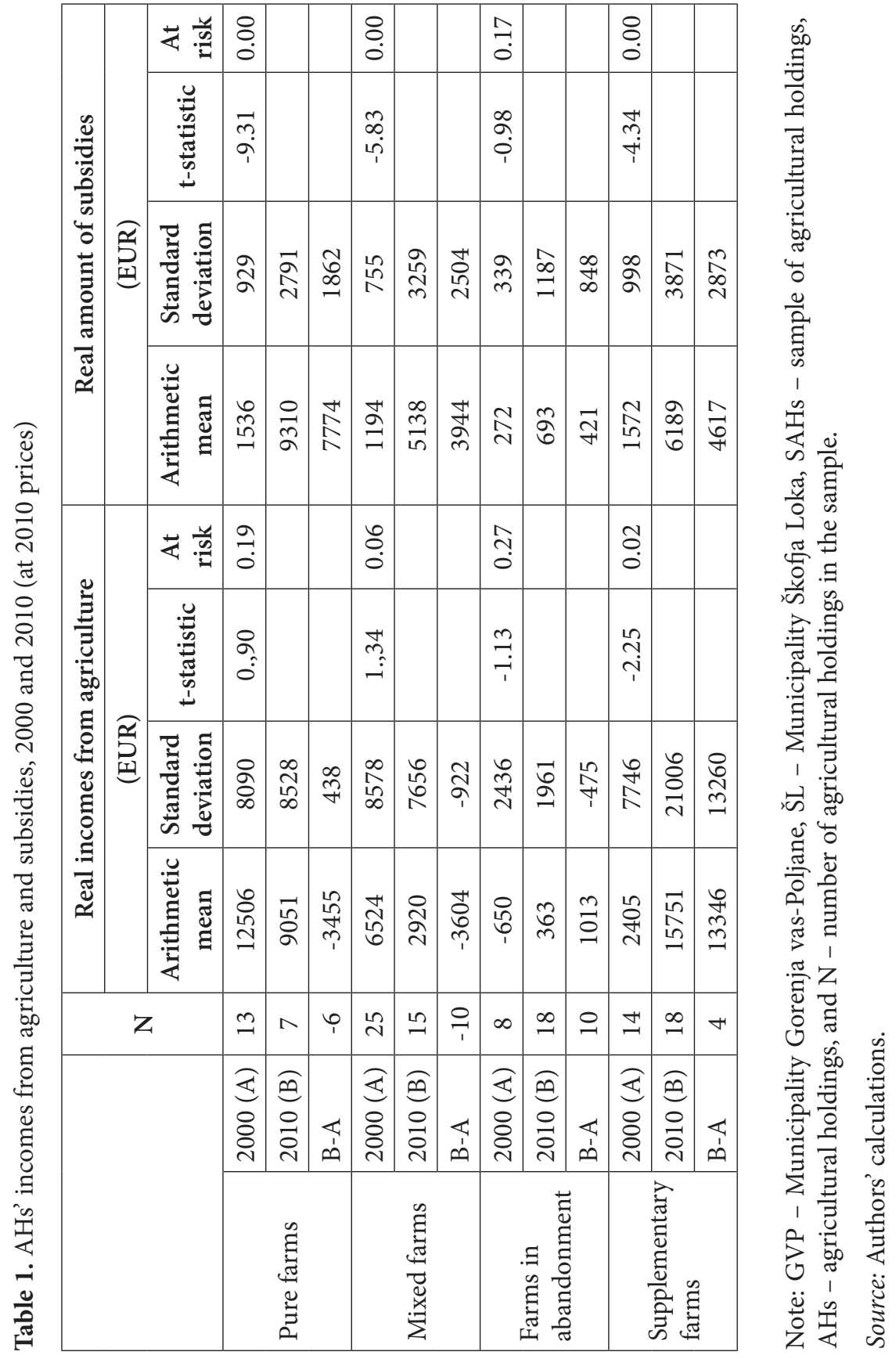




\section{Incomes of $\mathrm{AHs}$}

In 2010, real incomes from agricultural activities in AHs were lower than in 2000, except for supplementary farms. This was despite the fact that the state support to agriculture increased by almost four times (Table 1).

Incomes of AHs from agricultural activities for the majority of AHs also six years after the Slovenian accession to the EU are not sufficient for survival. The income situation of AHs between the years 2000 and 2010 for the majority of AHs relatively deteriorated, in spite of the higher state support to agricultural activities on AHs (Knific 2013).

In 2010, the highest average amounts of subsidies received per farm were for pure farms. This finding is attributed to the farm size in terms of the utilised agricultural area (UAA), the dominance of decoupled payments in that year, and the less favoured natural conditions for agricultural production in general in these hilly-mountain rural areas. Based on this finding, it can be concluded that the Common Agricultural Policy measures, structural policy, and rural development policy mitigate the unfavourable income situation of AHs in agricultural activities and maintain agricultural production in these less favoured hilly-mountain rural areas.

The drop in real incomes from agriculture - without subsidies - is attributed to the fall in real prices for some agricultural products when applying the rules of the common market to the accession of Slovenia to the EU, and the faster increase in prices of agricultural inputs than in prices of agricultural products.

In addition, the analysis of the databases of agricultural censuses in the years 2000 and 2010 shows an increase in the use of labour of AHs in agricultural activities (Knific 2015). The increased workload is found primarily in supplementary farms. It is attributed to the increased number of available manpower in AHs.

According to the questionnaire results, for supplementary farms with relatively high incomes from agriculture, it is typical that they have achieved higher prices for products of primary agricultural production (mainly meat and milk). In the context of supplementary activities, which are dominated by tourism on farms and the processing of agricultural products, primary agricultural products are processed and sold at home or at farmers' markets at higher prices. Farm diversification towards tourism has been observed also in other countries (Hjalager 1996; Baum 2011). 
The lagging of incomes of AHs behind incomes from non-agricultural employment increased between the years 2000 and 2010 (Knific 2013). The lagging of incomes from agriculture behind incomes from off-farm employment resulted in a two-way structural change in the AHs in Škofjeloška rural areas: firstly, the abandonment of agricultural production (full and partial) and increasing economies of scale in the remaining larger and more specialised farms, and secondly, the changes in labour allocation from agricultural activities to non-agricultural employment and income diversification. In terms of success in income diversification of AHs, the supplementary farms have most successfully adapted to this change. This is consistent with the findings of some other studies, and typical for the larger and more specialised AH farms (Fernádez-Corenjo et al. 2007; Bojnec and Latruffe 2009, 2013; Bojnec and Fertő 2013).

According to the questionnaire results, supplementary activity, which in the AHs includes the processing of products of primary agricultural activities, allows AHs to achieve higher prices of primary agricultural production and additional income from supplementary activities. Supplementary farms in the sample of AHs have made a decision to diversify incomes with supplementary activity, primarily to ensure a steady source of income of AHs, to increase the standard of living of AHs, and to ensure a source of funds for investment in primary agricultural activity. In addition, they perceived market opportunities and higher efficiency in labour allocation than in the primary agricultural activities.

The number of AHs with supplementary activity increased faster in the municipality of Škofja Loka than in Gorenje vas-Poljane. In addition, in 2010, farms with supplementary activities in the municipality of Škofja Loka reached a higher income than the supplementary farms in the municipality of Gorenje vas-Poljane. In 2000, there were no such significant differences. In 2010, differences between supplementary farms in the municipalities are attributed to greater proximity to local markets in the municipality of Škofja Loka (local free market in town centres and tourism), better natural conditions for agricultural production, and a somewhat stronger focus of supplementary farms in the municipality of Škofja Loka on higher efficiency in the use of production factors, mainly labour (Knific 2013). 


\section{Diversification of incomes of AHs}

Diversification of incomes of AHs with off-farm employment remains, in addition to other revenues and remunerations of $\mathrm{AH}$ members, the most important income source of AHs. Off-farm employment and off-farm incomes play a crucial role for AHs' survival and to provide funds for investments, including the education of children. Off-farm incomes are also often a source of funds for investment in the agricultural activity (Knific 2013; Bojnec and Fertö 2013). Other revenues and remunerations of $\mathrm{AH}$ members were an important source of revenues of AHs in Škofjeloška hilly-mountain rural areas, while the other sources of incomes between socio-economic types of AHs varied significantly.

For pure farms, incomes from agricultural activities were important. For mixed farms and farms in abandonment, incomes from off-farm employment were important. For the supplementary farms, all sources of incomes from agricultural activities, self-employment, and off-farm employment were important (Knific 2013).

Maintaining an active multifunctional role of AHs through the implementation of primary agricultural activity of AHs in hilly-mountain rural areas is worrying, especially while considering the unfavourable income situation of mixed and pure farms, as well as farms in abandonment in less favoured areas for agricultural production (Knific 2013). Opportunities to diversify incomes through supplementary activities are smaller, mainly for AHs in marginal hilly-mountain areas, for AHs with less favourable characteristics of members of AHs in terms of age, knowledge and entrepreneurship, for AHs with relatively little labour to carry out agricultural activities due to off-farm employment and labour migration from AHs and rural areas, and for farms with inadequate capital to start the business. In this context, expanding the scope of supplementary activities in AHs is becoming relatively limited due to limited local demand, legal constraints, and resources in AHs in terms of products of primary agricultural production and available labour. On the other hand, sufficient horizontal and vertical linkages of AHs are not established in the marketing of products and in the supply of inputs, as well as in the diversification of products in the distinctive higher value-added quality products (Knific 2013). 
Objectives of the socio-economic types of farms in farming Strategies of AHs in the sample are consistent with the family household farming objectives. Their goals primarily do not seek to maximise profits, but rather are focusing towards preserving family tradition and the survival of AHs (Table 2). However, economic survival of AHs is associated with economic efficiency and sufficient incomes of AHs for long-term survival.

Therefore, AHs from an economic perspective can often make irrational decisions. Economic objectives of farms are also geared towards the efficient allocation of production factors. Labour is one of the flexible factors in AHs. On the other hand, UAA, if natural conditions are appropriate, provides a variety of production orientations. Facilities and equipment are generally useful narrowly for specifically targeted needs (Knific 2013).

The objectives of AHs have various impacts on structural changes. In areas with better natural conditions for agricultural production, they can inhibit structural changes in agriculture, reflecting mainly slower abandonment and exiting from the agricultural production of small farms, which limits the increase in size of the remaining AHs. In marginal, less favoured hilly-mountain areas with a natural handicap for agricultural production, the renting of land or purchase of agricultural land by the remaining AHs is often less important or not interesting. This is especially due to low revenues and high production costs, distances and requirements for specialised machinery in hilly-mountain areas (Knific 2013).

The identified objectives of AHs do not inhibit structural changes on AHs. In these less favoured hilly-mountain areas, there is an alternative of agricultural production in the reforestation of agricultural land to forests. AHs' objectives are related to the preservation of family tradition in these areas that maintain agricultural activity even if the results of the agricultural activity in AHs are less favourable in economic terms. This refers mainly to the transfer of the farm to a successor.

According to the questionnaire results, the adapting of AHs to external changes takes time, but the response time between socio-economic types of AHs is different. The sample of AHs is dominated by gradual adaptation to changes such as policy measures, prices of agricultural products, and inputs. On the other hand, most of the pure farms track changes and react to them later on with their implementation. If the changes require adjustment in production orientations, then the adjustment of pure farms is slowing 
[29]

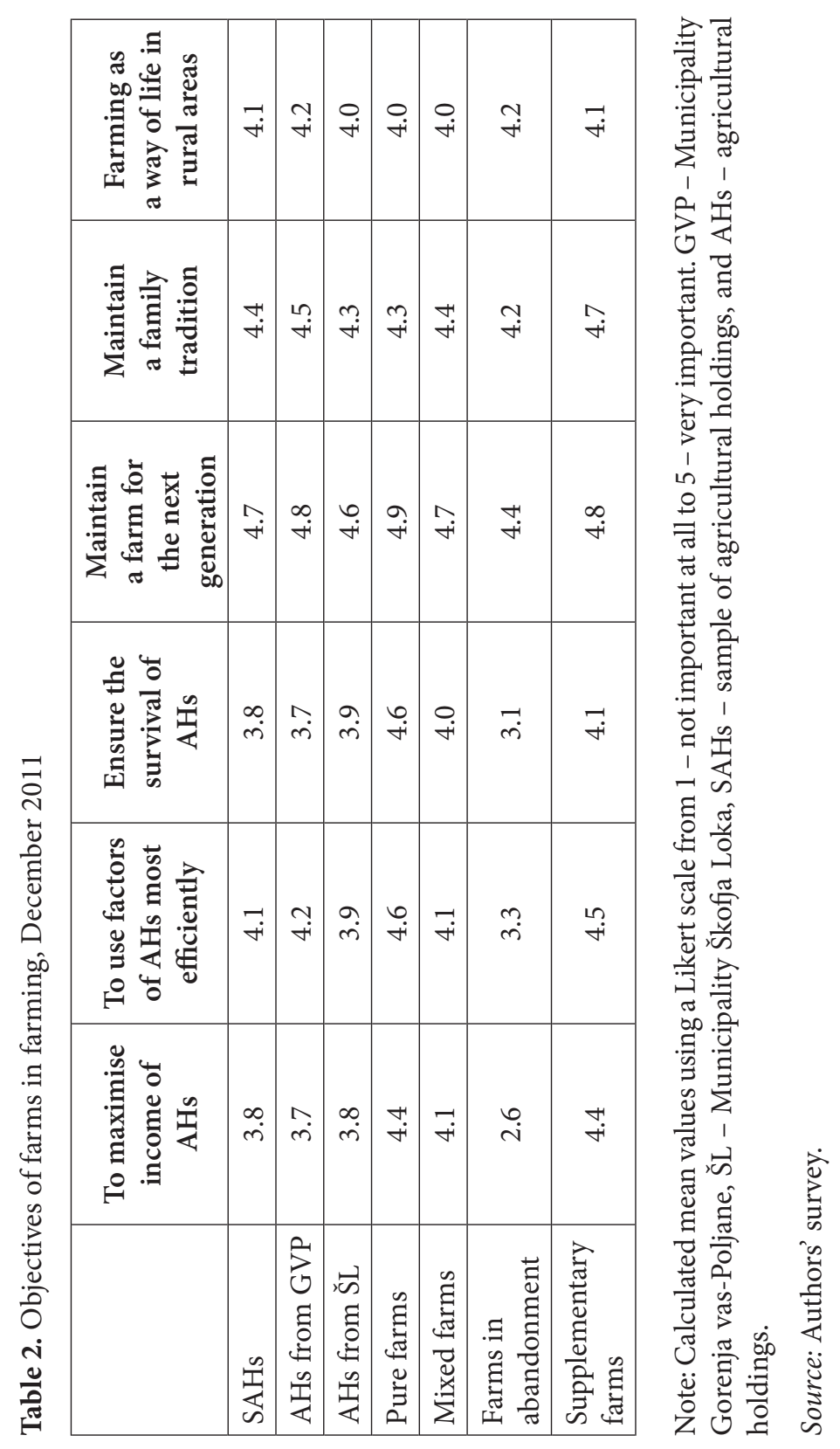


down, mainly due to insufficient financial resources and attitude towards risk in hiring loans. Concerning the owners of pure family farms, this is attributed mainly to the unfavourable income situation of the AHs.

Diversification of incomes with non-agricultural employment is inevitable for the survival of most AHs in the sample. Similarly, as noted by Bojnec and Dries (2005), the questionnaire results on the attitude of the members of the AHs towards income diversification with off-farm employment depend on the age and education of AH members (Knific 2013). Diversification of incomes with supplementary activity is favoured more by the younger members of AHs with vocational or secondary employment, while those with a university education give priority to offfarm employment. Off-farm employment can have two-way influences on the structural changes in agriculture in AHs in Škofjeloška hilly-mountain rural areas. Firstly, non-agricultural employment with supplementary activities on farms that are not related to the processing of products from primary agricultural production and regular off-farm employment is the first step towards reducing the volume and change in the structure of agricultural production, especially if it is labour-intensive, such as milk production, and if the sources of labour on $\mathrm{AHs}$ are restricted to the $\mathrm{AH}$ members with off-farm jobs and those school and university students studying away from these hilly-mountain rural AH places. Supplementary activities on farms that are associated with the processing of agricultural products in the sample of AHs provide opportunities for maintenance and development of primary agricultural activities. They can increase revenues from primary agricultural activities due to higher prices for higher valueadded products. They can also provide a source of funds for investments in farms in agricultural and non-agricultural activities.

Members of AHs dealing with supplementary activities on the farm can often easier follow the needs of the work in AHs in primary agricultural activities than members of AHs who are in off-farm employment. According to the questionnaire results, most of the work in agricultural activity in AHs in Škofjeloška hilly-mountain rural areas is carried out by the core of AH members. Traditionally, the head of AHs is the most engaged in terms of maintaining agricultural production. The employment status of the $\mathrm{AH}$ head is crucial for agricultural activity and for the transfer of AH functions to a successor (see also Knific and Bojnec 2009; Knific 2013). 
According to the questionnaire results, an abandonment of farming on commercial farms most likely can occur when changing the head of AHs, especially if non-agricultural employment is ensuring AH survival and the farm is economically too small to ensure parity income of at least one of the members of AHs. Most of the heads of AHs believe that their farm is economically too small, mainly due to limited natural conditions and low incomes from agricultural activities.

According to the questionnaire results, farms in abandonment, mainly due to the low dependence on incomes from agriculture, preserve land ownership due to social reasons, property security, and the preservation of the farm for successors. This also limits the supply of land and maintains its relatively high price, especially in areas where the soil is of higher quality and commercial farms have a tendency to increase their economies of scale. This can inhibit the pace of structural change in areas with better natural conditions for agricultural production. While in marginal areas with difficult production conditions and the most diverse terrain, this can have a minor or no effect on the pace of structural change in agriculture, it can potentially keep the cultivation of agricultural land.

\section{Conclusion}

Slovenia's accession to the EU has influenced the AHs in the Škofjeloška rural areas, mainly the incomes of AHs. This is reflected in the change in incomes of AHs from agricultural and non-agricultural activities, and in changes by socio-economic types of AHs.

Structural changes in the AHs in Škofjeloška hilly-mountain rural areas are confirmed by reducing the number of AHs due to exiting from the sector and the change in the socio-economic type of remaining AHs. Differences are found in the speed of structural changes. This can be explained by different natural factor endowments for agricultural production and proximity to urban centres (see also Knific and Bojnec 2015). Incomes of AHs from agriculture for the majority of AHs, even six years after the Slovenian accession to the EU, are not sufficient for survival. Between 2000 and 2010, the income situation for the majority of AHs relatively deteriorated, in spite of the relatively higher state support or subsidies for agricultural activities of AHs. An unfavourable income situation has forced AHs into structural changes, particularly to the abandonment of 
agricultural production. This is reflected, in particular, by reducing the number of AHs, and increasing the economies of scale in the remaining AHs, and has led to the change in the socio-economic type of AHs with the increasing role of income diversification. The speed of abandonment of farming activities due to the lack of profitability has been mitigated by non-economic objectives related to the tradition of AHs, which are oriented towards the preservation of farms and agricultural activities as long as possible. The adaptation of farms in the form of restructuring and structural changes to market conditions is also hampered by insufficient financial resources for necessary investments and the attitude towards the risks or risk aversion of traditional farms associated with the hiring of loans.

Among socio-economic types of farms, supplementary farms have most successfully adapted to changes. Between 2000 and 2010, the number of supplementary farms increased. The most successful by income were those from areas with better natural conditions for agricultural production and proximity to urban centres. Opportunities to diversify incomes through supplementary activities are smaller, mainly for AHs in marginal areas, for AHs with less favourable characteristics of members of AHs in terms of age, knowledge and entrepreneurship, and for AHs with relatively little labour to carry out agricultural activities due to off-farm employment and migration of AH members from farm and rural areas, as well as inadequate capital to start the business. The number of mixed and pure farms has decreased, while the number of farms in abandonment has increased.

Diversification of incomes with non-agricultural employment and off-farm incomes for most of the AHs in the sample is inevitable for their survival. This has a two-way influence on structural changes in Škofjeloška rural areas.

Firstly, it affects non-agricultural employment with supplementary activities on farms that are not related to the processing of primary agricultural production. Yet, in full-time off-farm employment, mainly due to higher incomes or higher labour productivity, it represents the first step towards reducing the size and change in the type of agricultural production.

The first step with a lag is followed by a second step with the exiting and abandonment of agricultural production. Land in favourable conditions for agricultural production can be rented out and/or sold, while in marginal areas it can be uncultivated land and/or land in reforestation. 
Supplementary activities on farms that are associated with the processing of agricultural products of AHs allow the preservation and development of primary agricultural activities. On the one hand, they increase revenues from primary agricultural activities due to higher prices for higher value-added products; on the other hand, they provide a source of funds for investment. Since most of the work in agricultural activity on AHs in Škofjeloška rural areas is carried out by the core of AH members, particularly by the head of the farm, in terms of maintaining agricultural production it is important, in particular, for the employment status of the head of the farm and for the successful transfer of functions to a successor.

Abandonment of agricultural production on farms is most likely at a stage of transfer of the farm to a successor, especially if non-agricultural employment and off-farm incomes are ensuring the economic survival and if the farm is economically too small to be able to ensure parity income of at least one of the members of AHs.

\section{References}

Baum, S. (2011), 'The Tourist Potential of Rural Areas in Poland', Eastern European Countryside, vol. 17, pp. 107-135. [DOI: 10.2478/v10130-011-0006-z]

Bojnec, Š. and Dries, L. (2005), 'Causes of Changes in Agricultural Employment in Slovenia: Evidence from Micro-Data', Journal of Agricultural Economics, vol. 56 (3), pp. 399-416.

Bojnec, Š. and Fertö, I. (2013), 'Farm Income Sources, Farm Size and Farm Technical Efficiency in Slovenia, Post-Communist Economies, vol. 25 (3), pp. 343-356.

Bojnec, Š. and Latruffe, L. (2009), 'Determinants of Technical Efficiency of Slovenian Farms', Post-Communist Economies, vol. 21 (1), pp. 117-124.

Bojnec, Ś. and Latruffe, L. (2013), 'Farm Size, Agricultural Subsidies and Farm Performance in Slovenia, Land Use Policy, vol. 32, pp. 207-217.

EC (2002), EC-PHARE Project No. P98-1090-R, EU Accession in the Balkans, Policy Options for Diversification in the Rural Economy, Final Report. Brussels: European Commission.

Eurostat (2012), Farm Accounting Data Network: an A to $Z$ of methodology. Luxembourg: European Commission.

Fernandez-Cornejo, J., Ashok, M., Nehring, R., Hendricks, C., Southern, M. and Gregory, A. (2007), 'Off-Farm Income, Technology Adoption, and Farm 
Economic Performance', Washington, DC: USDA, Economic Research Service.

Hjalager, A.-M. (1996), 'Agricultural Diversification into Tourism: Evidence of a European Community Development Program', Tourism Management, vol. 17 (2), pp. 103-111.

Knific, K. (2013), Analiza strukturnih sprememb kmečkih gospodinjstev na območju Škofjeloškega podeželja [Analysis of structural changes in agricultural households in Škofjeloška rural areas]. PhD thesis. Koper: University of Primorska, Faculty of Management.

Knific, K. and Bojnec, Š. (2009), Diverzifikacija dohodkov gospodinjstev na hribovitem podeželskem območju [Diversification of incomes of agricultural holdings in hilly rural areas]. Koper: Faculty of Management.

Knific, K. and Bojnec, Š. (2015), 'Structural Changes in Land Use of Agricultural Holdings in Hilly Rural Areas: The Case of the Škofja Loka Region', Acta Geographica Slovenica, vol. 55, in press, http://ojs.zrc-sazu.si/ags/article/ view/736/0.

Kovačič, M. (1996), Socio-ekonomska in velikostna struktura kmetij v Sloveniji v obdobju 1981-1991 [Socio-economic and size structure of farms in Slovenia 1981-1991]. Ljubljana: University of Ljubljana, Biotechnical Faculty.

MAFF (2007), Program razvoja podeželja za Republiko Slovenijo 2007-2013 [Programme of rural development for the Republic of Slovenia 2007-2013]. Ljubljana: Ministry of Agriculture, Forestry and Food.

Möllers, J. (2006), Außerlandwirtschaftliche Diversifikation im Transformationsprozess [Non-agricultural diversification in the transition process]. Halle: IAMO.

Möllers, J. (2007), Questionnaire for Households. Halle: IAMO.

Oblak, O. (2002), Ocena skupnega dohodka na kmečkih gospodinjstvih v Sloveniji [Estimate of the total income in farm households in Slovenia]. Master thesis. Ljubljana: University of Ljubljana, Biotechnical Faculty.

SORS (2005), Statistical Yearbook of Slovenia 2005. Ljubljana: Statistical Office of the Republic of Slovenia.

SORS (2012a), Revaluation of Cash and Cash Equivalents. Ljubljana: SORS.

SORS (2012b), Statistical Yearbook of Slovenia 2012. Ljubljana: SORS.

Udovič, A., Kovačič, M. and Kramarič, F. (2006), Socio-ekonomski tipi kmetij po podatkih popisa kmetijskih gospodarstev v letu 2000 [Socio-economic farm types according to the census of agricultural holdings in 2000]. Slovenija v EU, izzivi za kmetijstvo, živilstvo in podeželje [Slovenia in the EU, challenges for agriculture, food and rural areas]. Ljubljana: DAES, pp. 71-80. 